Volume: 11 Issue: 2 Year: 2014

\title{
Young athletes' perceptions of a psychological preparation intervention
}

\author{
Tuomas Nikupeteri ${ }^{1}$ \\ Satu Uusiautti ${ }^{2}$ \\ Kaarina Määttä3
}

\begin{abstract}
This article reports a study concerning a psychological preparation intervention in sport environment. The method implemented included performance profiling and goal setting. The purpose of this study is to evaluate the intervention from the young athletes' point of view. The research task was to analyze how the athletes perceived the intervention, its benefits and weaknesses. The questionnaire data were obtained alongside the intervention case study among 61 young athletes from a sport academy in northern Finland. Their answers were analyzed with the qualitative content analysis. For some of the athletes, the intervention worked as planned increasing their self-knowledge, motivation, concentration, and personal training, while others did not perceive the intervention very meaningful of beneficial. Based on the young athletes' experiences, suggestions for future psychological preparation interventions are presented.
\end{abstract}

Keywords: Sport psychology; Performance profiling; Goals; Evaluation; Intervention; Psychological preparation.

\section{Introduction}

Psychological preparation and sport psychology make quite a topical topic arousing discussion in Finnish sport (e.g., Lintunen et al., 2012; Matikka, 2012) and internationally (e.g., Blumenstein, Lidor, \& Tenenbaum, 2007; Kremer \& Moran, 2008). Diverging opinions have been expressed about how and which instances should provide this kind of psychological preparation and, the lack of studies focusing on the applied sport psychology, the practical uses of psychological preparation, has been noticed (e.g., Blom, Visek, \& Harris, 2013; Tashman \& Tenenbaum, 2013).

\footnotetext{
${ }^{1}$ MA, University of Lapland, Faculty of Education, tuomas.nikupeteri@hotmail.fi

2 Ph.D., Adjunct Professor, Researcher, University of Lapland, Faculty of Education, satu@uusiautti.fi

3 Ph.D., Professor, University of Lapland, Faculty of Education, Kaarina.Maatta@ulapland.fi
} 
Nikupeteri, T., Uusiautti, S., \& Määttä, K. (2014). Young athletes' perceptions of a psychological preparation intervention. International Journal of Human Sciences, 11(2), 609-624. doi: 10.14687/ijhs.v11i2.2941

The intervention on which this article focuses was executed in a sport academy located in northern Finland. It is a network of education institutions and partners in collaboration aiming at making training of top athletes' and athletes pursuing the top more efficient and at supporting athletes' studies.

The data of this article are based on a case study that evaluated the psychological preparation intervention implemented during the study year of 2012-2013 at the sport academy. The current idea of the Finnish Olympics Committee is "the athlete in the center" (see Finnish Olympics Committee, 2012) and therefore, the study also wanted to focus on young athletes' personal opinions on and experiences about the intervention.

\section{Psychological Preparation}

Sport psychology is a branch of science researching human behavior in the environment of sport and exercising: sport psychological knowledge is to help not only top athletes but also active and passive exercisers (Matikka \& Roos-Salmi, 2012). Sport psychology can also be seen as a synonym for training psychology (e.g., Lintunen et al., 2012; Orlick \& Partington, 1988). The latter refers to a holistic process including community-, group-, and individual-level methods and solutions of training that support and enhances the well-being and personality development in athletes and trainers. Training psychology refers to those solutions that are to exercise psychological skills and help to encounter stress situations in sport and cope with mental problems. Every training situation at every level of performance involve training psychology (Lintunen, Rovio, Haarala, Orava, Westerlund, \& Ruiz, 2012).

Training psychology, in other words, psychological preparation, is quite a wide entity and a part of daily training activities. The objectives of psychological preparation can be divided into (1) training that supports mental well-being, (2) teaching of mental skills or techniques, and (3) treating mental problems (Lintunen, 2012). The method of psychological preparation are and they should be holistic interventions and not just learning of singular skills. The intervention evaluated in this article is a combination of the first two dimensions of psychological preparation. The intervention aimed at teaching athletes one technique of psychological preparation by complementing it with profiling everyone's own performances that can also be considered a psychological skill. On the other hand, the purpose was to develop interaction and training processes between the athletes and their trainers. When considered from a wider perspective, the starting point of the intervention was to create a training method for the sport organization that would support the personality 
Nikupeteri, T., Uusiautti, S., \& Määttä, K. (2014). Young athletes' perceptions of a psychological preparation intervention. International Journal of Human Sciences, 11(2), 609-624. doi: 10.14687/ijhs.v11i2.2941

development and development of performances in athletes. Although the intervention did not cover the treatment of mental problems, it aimed at noticing the holistic nature of psychological methods.

Psychological preparation is functional influencing (Morgan, 1974). The trainer tries to influence the athlete's behavior so that he or she can achieve his or her performance goals. Methods of psychological preparation are mental, cognitive- and emotional-level tools. Both athletes and trainers use these mental methods: the former for preparing themselves and the latter for coaching. Sport psychology differs from psychological preparation in its aims: the purpose of sport psychology is not necessarily to achieve any certain results but to understand human behavior as a phenomenon (Matikka, 2012).

In sport psychology, performance is considered prone to various psychological processes including psychological skills and techniques (Driskell, Copper, \& Moran, 1997). According to research, athletes and trainers can improve psychological skills with various techniques of psychological preparation. One of the biggest advantages of practicing psychological skills is that already learning of one technique of psychological preparation influences several psychological skills (Cox, 2012; Matikka, 2012). For example, efficient goal-setting strengthens self-esteem which again improves motivation and concentration. Such techniques of psychological preparation are the practical tools provided by sport psychology (Roos-Salmi, 2012). According to Weinberg and Gould (2007), there are four basic methods of psychological exercising and training: (1) regulation of one's alertness, (2) mental image exercises, (3) goal-setting, and (4) concentration and focus.

Sport psychology uses various terms when talking about athletes' psychological preparation, such as mental skills training (MST) or psychological skills training (PST). However, psychological preparation usually refer to the systematic learning of those methods that are to increase athletes' abilities to use their minds and thoughts efficiently and that prepare them for realizing and achieving their sport-related goals (see Gould \& Carson, 2007; Weinberg \& Gould, 2007).

For clarity, this article uses only just one concept—psychological preparation-when referring to the practicing and training of mental or psychological skills. When using the concept, it will be separately distinguished whether it discusses athletes' preparation or trainers' coaching. When necessary, it will also be clarified whether the question is about a psychological skill or about a method or technique.

What is important in implementation of psychological preparation is to integrate it as a part of daily training activities (Weinberg \& Gould, 2007). Psychological preparation has to be connected 

intervention. International Journal of Human Sciences, 11(2), 609-624. doi: 10.14687/ijhs.v11i2.2941

naturally and efficiently with all other parts of training, such as physical, tactical, or technical preparation. The closer these different areas get or the more it is possible to combine them into entities, the more likely will they influence positively on the successful realization of a training program (e.g., Martindale, Collings, \& Daubney, 2005). Likewise, wide-ranging interaction between all participants and partners is one of the key elements of successful implementation (Blumenstein, Lidor, \& Tenenbaum, 2007). In all, Martindale, Collins, and Daubney (2005) summarize that there are five key generic features that constitute to a successful development process in sport: (1) longterm aims and methods; (2) wide ranging coherent messages and support; (3) emphasis on appropriate development rather than early selection; (4) individualized and ongoing development; and (5) integrated, holistic, and systematic development.

The realization of psychological preparation can be divided into three phases (Weinberg \& Gould, 2007): In the instruction phase, athletes are given the basic information about the skill to be practiced, reasons why the skill is important, and examples of how it can be used. The second phase is when the skill is acquired. Athletes are shown various strategies and techniques that help them achieve the skill. The third phase is practicing. It aims at having the skill becoming automatic and at integrating it systematically in the performance situations. The skill will also be used for stimulating skills that are supposed to be used in a competition situation. The ultimate goal of psychological preparation is athletes' self-regulation. Self-regulation is such goal-oriented action through which an athlete constantly recognizes and observes, and controls his or her thoughts, emotions, and behavior (Weinberg \& Gould, 2007). This article introduces the implementation of one method of psychological preparation in a sport academy from the perspective of young athletes.

\section{Method}

\section{Research questions}

This study analyzed how the young athletes of at a sport academy experienced psychological preparation intervention taking place in 2012-2013.

Two research questions were set for this study:

(1) What are the positive factors and experienced influence of the psychological preparation intervention according to the young athletes' perceptions? 
Nikupeteri, T., Uusiautti, S., \& Määttä, K. (2014). Young athletes' perceptions of a psychological preparation intervention. International Journal of Human Sciences, 11(2), 609-624. doi: 10.14687/ijhs.v11i2.2941

(2) What are the challenges, weaknesses, and needs for change of the psychological preparation intervention according to the young athletes' perceptions?

Based on the perceptions and in the light of the sport psychological literature, the purpose of this study is also to analyze how psychological preparation could be developed and what should be taken into account in future interventions.

\section{Data and Data Collection}

This study was a part of a larger case study realizing a psychological intervention at the sport academy that formed the context of this study. This study leaned on the paradigmatic model and methodological pluralism (see Karjalainen, 2007; Kuusela, 2004). The approach used in the study was descriptive as the purpose was to evaluate and describe, not to explain the intervention (see Syrjälä \& Numminen, 1988). The data obtained included evaluations of the influence and processes of psychological preparation, students' satisfaction with the intervention, and their perceptions of the overall influence of the intervention (see also Robson, 2001; Vartiainen, 2001; 2007). In this article, we report the analysis of the processes of psychological preparation and customer satisfaction as described by the students.

The young athletes $(\mathrm{N}=61)$ who participated in this study were students at secondary school level, aged from 14 to 20. The original number of athletes participating in the intervention was 205, which means that only about $30 \%$ participated in evaluation. They filled out the profiling forms and goal-setting forms independently at the end of the year 2012. The forms were part of the psychological preparation intervention, and preparation was designed according to the forms during the winter 2012 and spring 2013. The students were informed of the purposes of the forms. After the preparation period, the students were asked to evaluate the intervention, which can be considered the follow-up data. The form had structured and open questions (Messick, 1995).

Therefore, the follow-up data of this study included formative evaluations that had two purposes: the athletes were asked to answer questions concerning the implementation and influence of the intervention. In addition, the evaluation was used as a part of the continuous evaluation of the organization providing training in sports to improve their training methods and customer satisfaction (see also Robson, 2001; Virtanen, 2007).

The context in which the study took place was a sport academy located in northern Finland. It provides training in various sports such as downhill skiing, volleyball, cross-country skiing, ski jump, Nordic combined, soccer, ice hockey, swimming, and athletics. The academy has both fulltime and part-time coaches. They are assisted by physical education instructor students from local 
Nikupeteri, T., Uusiautti, S., \& Määttä, K. (2014). Young athletes’ perceptions of a psychological preparation intervention. International Journal of Human Sciences, 11(2), 609-624. doi: 10.14687/ijhs.v11i2.2941

education institutions. These students work as assistant coaches and training developers. These professionals together with the top athletics coordinator implemented the psychological preparation intervention.

Answers provided to open questions were analyzed with theory-bound content analysis. The phases of analysis included reduction, grouping, and conceptualization (Tuomi \& Sarajärvi, 2009). The analysis leans on literature of sport psychology which has functioned as a framework for this study (see also Eskola, 2007).

The results are next introduced as answers to the research questions. The result section also includes excerpts from the data. In order to guarantee the athletes' anonymity, they are referred to with a letter-number combination (from ht1 to ht61), each athlete having his or her own number.

\section{Results}

\section{Perceived Positive Factors and Influence of the Psychological Preparation}

The young athletes participating in this research named several positive factors and influence that the psychological preparation intervention had had. First, they were satisfied with the increase in their self-knowledge. With the profiling and goal-setting forms, they had to analyze their performances, which helped them to recognize needs for development as well as strengths in themselves as athletes and the positive in their performances. The participants described the development, for example, as follows:

bt8: filling out the goal-setting form developed and clarified things about myself as an athlete

bt33: self-evaluation tanght much about myself and how to develop myself

bt37: you learn to know your best sides and weaknesses

Because of the increase in self-knowledge, some athletes reported that they were now able to plan their action better and more specifically and to clarify their concentration and action with the method introduced in the psychological preparation. Their training had turned into more systematic and organized, but also more individualistic.

ht10: you bave your own intermediate goals in your mind and are aware of what you are doing bt14: more personalized attention to issues you have to develop

Eventually, increasing self-knowledge and more specified training programs were also connected with motivation, which is quite a familiar concept among athletes. Many athletes described how the 
Nikupeteri, T., Uusiautti, S., \& Määttä, K. (2014). Young athletes’ perceptions of a psychological preparation intervention. International Journal of Human Sciences, 11(2), 609-624. doi: 10.14687/ijhs.v11i2.2941

psychological preparation had increased their motivation toward their sport hobby and selfdevelopment. Increase in motivation can be explained by not only increasing awareness of one's skills, but also by suitable, achievable goals. Well-defined goals were reported to boost practicing:

ht8: increased motivation because you knew where to aim and what to develop

bt27: goal-setting discussions strengthened motivation to train

bt29: clear aims and goals are motivating

All this knowledge helped athletes also plan their programs further in the future. Extending time span was perceived useful and positive. Indeed, the purpose of the psychological preparation was not only to direct concentration and action, but also to provide long-term goals that also form a well-planned, balanced, and clear basis for training. This was described by the athletes in the following manner:

ht8: it helped to clarify goals and the route toward goals

bt48: I guess I bad to think about clear goals and what I really want [in the future]

\section{Challenges, Weaknesses, and Needs for Change in the Psychological Preparation}

\section{Intervention}

Three major issues emerged from the data when analyzing the implementation of the psychological preparation as described by the athletes. First, the athletes reported that filling out the questionnaire was challenging. Challenges were related to time and lack of skills to evaluate one's performances and setting goals. It seemed that they would have needed more instructions on how to profile themselves, what the grounds of self-evaluation were, and what to compare their performances with. The following data excerpts illustrate how the young athletes described these problems:

bt7: filling out the forms was time-consuming and challenging

ht9: filling out forms was difficult and hard also mentally because you had to say aloud you weaknesses bt19: goal-setting was difficult because it was not clear nor did I understand it t

bt60: it was difficult to think about strengths and weaknesses alone and how to develop them, the coach could have provided more concrete belp

The last of the aforementioned comments brings up the trainer's role. In order to successfully fill out the new and demanding self-evaluation forms, these young athletes would have benefitted from an adult's advice. Their trainers are probably the ones who know their performance levels the best, 
Nikupeteri, T., Uusiautti, S., \& Määttä, K. (2014). Young athletes’ perceptions of a psychological preparation intervention. International Journal of Human Sciences, 11(2), 609-624. doi: 10.14687/ijhs.v11i2.2941

but also the athletes as sportsmen and women, and as trainees. Many athletes in this study would have appreciated greater participation in making the self-evaluations from the trainer's side:

bt59: the questions were difficult and hard to understand because they just handed out the forms

According to the young athletes' perceptions, the second challenge was that even if they filled out the evaluation forms and set goals, it did not change training in any way. Therefore, these actions were seen separate from each other, which led to an experience that the intervention was meaningless. Their feelings of not becoming eventually heard and their opinions not becoming taken into account were evident in the data:

bt26: issues written in the forms were not transmitted in training at the academy

bt41: filling out those forms did not change training, the planned exercises that were planned were never realized, it was useless because we did not discuss them with the coach, at the moment it makes quite a separate and little part of preparation

As the first result chapter showed, perceived benefit was connected with clear personalized goals and motivation. However, all athletes did not share this experience. They argued that the goals were not taken into account well enough nor were they individualized enough. These athletes hoped that goal achievement would have been better and systematically followed several times during the intervention period. They also would have wanted to discuss their goals more profoundly and comprehensively in order to realize the importance of goals and their progress towards them:

bt8: regular follow-ups would be desirable, and there is plenty to develop

bt12: the forms should be read more carefully, the training did not focus on the athlete's needs and development sufficiently

In all, some of the athletes were dissatisfied with the amount of feedback they were given as well as the evaluation of psychological preparation during the intervention process.

bt27: there are problems in realization and testing, the level of feedback should be increased and it should be used better in training

The third weakness of the intervention was related to informing of athletes about the purposes and implementation of psychological preparation. Some athletes were unaware of the goals and meaning of the method. It was also alarming that some athletes were not even aware of that performance profiling and goal-setting made a part of psychological preparation and training of skills. These issues emerged from the data in several answers: 
Nikupeteri, T., Uusiautti, S., \& Määttä, K. (2014). Young athletes' perceptions of a psychological preparation intervention. International Journal of Human Sciences, 11(2), 609-624. doi: 10.14687/ijhs.v11i2.2941

bt9: it was unclear what these forms were aimed at influencing, and it was also unclear why I should do things that are not useful in practice, psychological preparation requires more than just a few forms and that the forms would count

bt27: it was not clear how I should have proceeded with this with my coach and what the benefit would have been

\section{Conclusion}

The intervention of psychological preparation analyzed in this study included profiling that could be used for self-evaluation and goal-setting. The young athletes' perceptions of the method varied considerably but are in line with previous research on the theme. For example, increasing selfknowledge is an important task of psychological preparation and its advantage: becoming aware of one's own strengths and weaknesses enables constant development (see Hulkari, 2006; Nikander, 2005). One of the most important objectives of goal-setting emerged from the data as well, namely, influence on motivation (Duda \& Treasure, 2006). This connection is widely studied in sport psychology (e.g., Cox, 2012; Rovio 2002; Weinberg \& Gould, 2007).

Likewise, psychological training had increased concentration and clarified personal goals in sport which also makes an important purpose of psychological training (Cox, 2012; Rovio, 2002; Thienot et al., 2014; Weinberg \& Gould, 2007). Performance profiling has proven to have the same advantage (Gleeson et al., 2005).

Those athletes who had positive experiences from the intervention reported that their training had become more organized and planned. In addition, some of them also appreciated the personalized preparation and considered that training had become more individualized during the intervention period. Especially, the performance profiling aims at building training programs that the athletes are motivated to follow and committed to. For several athletes, this intervention appeared successful as they had reached those benefits that the psychological preparation was supposed to provide them. When training is perceived personally meaningful, an athlete is likely to consider it motivating and engaging (see Newman \& Crespo, 2008).

Naturally, the realization of psychological preparation and goal-setting programs is always dependent on the interaction between people involved in it and on the situation in which these athletes and trainers work. Based on the findings of this study, the future interventions should pay special attention to how, where, and under whose directions the forms of psychological preparation are filled out (see also Weinberg \& Gould, 2007). Certain consistent instructions and following them carefully, as well as a specially selected place for filling out the forms make one practical 
Nikupeteri, T., Uusiautti, S., \& Määttä, K. (2014). Young athletes' perceptions of a psychological preparation intervention. International Journal of Human Sciences, 11(2), 609-624. doi: 10.14687/ijhs.v11i2.2941

solution that would make the self-evaluation process easier. In addition, help from the academy trainer or a student trainer would be desirable, downright a necessity (cf., Gearity \& Murray, 2011).

Athletes in this study mentioned that evaluation was challenging to do. This problem is good to know and relatively easily solved in future interventions because self-evaluation is a skill that can be practiced and learned when guided and encouraged (see Nikander, 2002; Sääkslahti et al., 2008). The psychological preparation implemented in this study and the self-evaluation or performance profiling could be done and practiced more often, and, for example first, without the wider and time-consuming goal-setting. Goal-setting is proven to be efficient only when it provides smaller steps along the way to long-term goals (e.g., Debois et al., 2012; Gilham \& Weiler, 2013). Furthermore, the role of academy trainers appears to be significant in trainees' practicing of selfevaluation because they can use their expertise and knowledge of athletes of the same sport and also their acquaintance with the trainee. In addition, it has also been shown that more positive adult sport involvement and interactions are connected with greater enjoyment in sports in young athletes (Scanlan \& Lewthwaite, 1986).

Sport psychological literature have recognized similar challenges in the realization of psychological preparation interventions and various viewpoints to the practical application of psychological knowledge are presented in sport psychological research (see e.g., Matikka \& Roos-Salmi, 2012). Weinberg and Gould (2007) have also reported of problems in interventions when the realization of preparation and the training process are not adequately observed and analyzed. In the future interventions of the sport academy, the evaluation, follow-up, and feedback given to athletes as significant parts of the psychological preparation must be better planned in interventions.

Likewise, athletes need concrete means of and methods to achieve goals, constant personal support, and evaluate and get feedback about the goals and their achievement (Gould \& Carson, 2007; Theodorakis et al. 2007; Weinberg \& Gould, 2007). This support should be offered by either the person responsible for intervention or trainers implementing the intervention. This does not mean that athletes themselves would not have to follow their goals and development. Training diaries or videoing practices can help (see Cox, 2012; Rovio, 2002; Weinberg \& Gould, 2007).

Finally, this study showed that it is also crucial to emphasize the meaning of psychological preparation and clarify its importance to athletes' development (Gould \& Carson, 2007). Therefore, future interventions have to be more carefully prepared to better inform athletes about the psychological preparation and to educate them about its theoretical foundations (Weinberg \& Gould, 2007). 
Nikupeteri, T., Uusiautti, S., \& Määttä, K. (2014). Young athletes' perceptions of a psychological preparation intervention. International Journal of Human Sciences, 11(2), 609-624. doi: 10.14687/ijhs.v11i2.2941

In all, the starting point to the intervention was good in this study but more emphasis was clearly needed for the preparation and informing of the participants. Integrating the intervention of psychological preparation in the daily training activities more clearly would be a reasonable solution in future interventions. After an adequate start-up, the eventual success of psychological intervention is up to athletes and trainers themselves.

\section{Discussion}

\section{Reliability of the Research and Research Ethical Considerations}

The reliability of the research can be discussed with traditional concepts provided to the evaluation of qualitative research (Lincoln \& Guba, 1985). First of all, this study was tightly theory-led, as presented at the beginning of this article. Systematic analysis, selection, and operationalization of the key concepts laid the foundation for the empirical realization of the research (see also Ivankova, Creswell, \& Stick, 2006). Of the core evaluation criteria by Lincoln and Guba (1985), transferability refers to the context and whether the researchers have provided sufficiently details of the context of the fieldwork. In this study, the context was described to the extent that would provide information about the participant and the research context, but would not reveal the participants' identities (see also Shenton, 2004). The dependability of the study can be criticized because such an intervention is impossible to repeat as such, not is it even practical: much was learned from this intervention, and the data obtained from the young athletes help improving the psychological preparation in this particular institution and provide practical information to other similar institutions as well.

Careful description of the select methods and data collection and analyses can strengthen the dependability and trustworthiness of the study (Shenton, 2004). The data implied, for example, that not all of the participants were sufficiently aware of the purposes of the questionnaire, which means that in the future, the importance and purpose of the profiling forms and evaluation questionnaires have to be stressed and carefully explained to athletes who participate in psychological preparation.

The fourth aspect to the reliability of the research is confirmability. It is a requirement of making interpretations based on the data and nothing but the data; thus, it is also about the researchers' self-reflection and ability to read the data as objectively as possible. The data were gathered from the athletes in the form of questionnaires, and the researcher's influence on the participants' answers can be considered relatively low. Data excerpts included in the results section were used 
Nikupeteri, T., Uusiautti, S., \& Määttä, K. (2014). Young athletes’ perceptions of a psychological preparation intervention. International Journal of Human Sciences, 11(2), 609-624. doi: 10.14687/ijhs.v11i2.2941

for illustrating the way the athletes described their opinions and experiences, and, also, to support the interpretations made from the data.

The original intervention was planned according to the goals and guidelines of psychological preparation and the sport academy implementing the intervention. Therefore, there were no specific ethical issues on the implementation of the study. The intervention was aiming at increasing the athletes' mental well-being and self-knowledge, and, through them, their performances in sport. This specific research reported in this article only focused on the data obtained from the athletes' initial evaluation forms and goal-setting plans, complemented with their after-intervention follow-up questionnaire. One of the researchers has acted as a trainer, too, and knows well the evaluation methods of psychological preparation. This aspect can be considered enhancing the study, because it provides practical understanding about the nature of training and its influence. However, the researcher's familiarity with the method can also have influenced the interpretations; the athletes' answers might have been interpreted more positively than the preparation was in reality. In addition, the evaluation of the psychological preparation was a part of the intervention and the operation of the sport academy. The low number of participants in this study compared to the whole group of athletes participating in the intervention might have biased the results to some extent. However, as the answers provided to the questionnaires and evaluation forms appeared versatile and brought up both the positive and negative sides as well as advantages and points needing developing in the psychological preparation, the data were considered sufficient.

All information provided by the athletes were handled with care to ensure their anonymity in the study. For example, the data excerpts do not even reveal the participants' gender or age. However, the purpose of the study was also to bring out the athletes' voices, in which the data seemed to succeed well.

\section{Implications and Further Discussions}

According to research, psychological preparation is efficient when it combines individual- and group-based methods and covers a whole training and competition period (Gould \& Carson, 2007). It is equally important to help athletes to understand psychological preparation as a part of everyday training. Williams et al. (2013) encourage considering the five Ws (Who, Where and When, Why, and What) in the planning stage of learning and implementing a new psychological method. They also have to learn about various singular psychological skills that they can combine in different way to improve their performances. Trainers need education in how to include psychological preparation in the training methods and other training activities they use. Methods and training 
Nikupeteri, T., Uusiautti, S., \& Määttä, K. (2014). Young athletes' perceptions of a psychological preparation intervention. International Journal of Human Sciences, 11(2), 609-624. doi: 10.14687/ijhs.v11i2.2941

programs have to be constantly evaluated for efficiency and suitability (Silva, Conroy, \& Zizzi, 1999).

Problems usually occur or psychological preparation fails when athletes and trainers are not convinced of the importance of a psychological skill or method, when time for practicing the method is too short, when the person introducing the intervention has not earned athletes' or trainers' trust for example due to insufficient sport-specific knowledge, or when the realization and process of psychological preparation is not observed carefully enough (Weinberg \& Gould, 2007).

An international research result reported by Cox (2012) showed that psychological preparation interventions aiming at improving sport performances have been successful in $85 \%$ of the cases as they have shown positive influence on performances. Why is that? These interventions have efficiently advanced self-esteem, concentration, eagerness to try, and performing. However, when evaluating psychological preparation and its efficiency, it is worth remembering that not all factors and events can be controlled and therefore it is difficult to show direct causal relationships about the influences of interventions. Likewise, generalizations have to be interpreted conservatively. Already the definition of psychological preparation affects the efficiency of intervention: whether the intervention focuses on how one or more psychological skills or technique or method of psychological preparation influence an athlete's results or performances (Gould \& Carson, 2007).

Indeed, Driskell, Copper, and Moral (1994) conclude that

although most researchers contend that mental practice is an effective means of enhancing performance, a clear consensus is precluded because (1) mental practice is often defined so loosely as to include almost any type of mental preparation and (2) empirical results are inconclusive. (p. 481)

For example, the intervention discussed in this study emphasized only one basic technique of psychological preparation, goal-setting. Although it had a positive influence on some athletes, the data included also those who did not benefit from it, or who perceived the intervention meaningless due to various reasons. However, the major contribution of this study can be also seen in the attempt of bringing our young athletes' voices and their opinions and experiences. As shown in the study, much can be learned from them especially when it comes to practical implementation of such interventions.

In all, the realization that human being's mind has an important role in all human action and performances_-including sport—makes interventions such as this one important (e.g., Thienot et al., 2014). Employing human resources as widely as possible (Määttä \& Uusiautti, 2014) unquestionably is one of the key elements in successful development as an athlete as well. 
Nikupeteri, T., Uusiautti, S., \& Määttä, K. (2014). Young athletes' perceptions of a psychological preparation intervention. International Journal of Human Sciences, 11(2), 609-624. doi: 10.14687/ijhs.v11i2.2941

\section{References}

Blom, L. C., Visek, A. J., \& Harris, B. S. (2013). Triangulation in youth sport: healthy partnerships among parents, coaches, and practitioners. Journal of Sport Psychology in Action, 4(2), 86-96. doi:10.1080/21520704.2012.763078

Blumenstein, B., Lidor, R., \& Tenenbaum, G. (2007). Sport psychology and the theory of sport training: an integrated approach. In B. Blumenstein, R. Lidor, \& G. Tenenbaum (Eds.), Psychology of sport training. Perspectives on sport and exercise psychology (pp. 8-18). Oxford: Meyer \& Meyer Sport Ltd.

Cox, R. H. (2012). Sport psychology. Concepts and applications. (7th ed.) New York, NY: McGraw-Hill.

Debois, N., Ledon, A., Argiolas, C., \& Rosnet, E. (2012). A lifespan perspective on transitions during a top sports career: A case of an elite female fencer. Psychology of Sport and Exercise, 13(5), 660668.

Driskell, J. E., Copper, C., \& Moran, A. (1994). Does mental practice enhance performance? Journal of Applied Psychology, 79(4), 481-492.

Duda, J. L., \& Treasure, D. C. (2006). Motivational processes and the facilitation of performance, persistence, and well-being in sport. In J. M. Williams (Ed.), Applied sport psychology: Personal growth to peak performance (pp. 57-81). New York, NY: McGraw-Hill.

Eskola, J. (2007). Laadullisen tutkimuksen juhannustaiat. Laadullisen aineiston analyysi vaihe vaiheelta [The midsummer magic of qualitative research. Qualitative data analysis phase by phase]. In J. Aaltola \& R. Valli (Eds.), Ikkunoita tutkimusmetodeibin 2 [Windows at research methods 2] (pp. 159-183). Jyväskylä: PS-Kustannus.

Finnish Olympics Committee. (2012). Suomalaisen buippu-urheilun muntos. Huippu-urheilun muntostyöryhmän loppuraportti [The change in the Finnish top sport. The final report of work group of change in top sport]. Retrieved from: www.noc.fi/@Bin/6112727/HuMu_loppuraportti_www.pdf

Gearity, B. T., \& Murray, M. A. (2011). Athletes' experiences of the psychological effects of poor coaching. Psychology of Sport and Exercise, 12(3), 213-221.

Gillham, A., \& Weiler, D. (2013). Goal setting with a college soccer team: What went right, and less-than-right. Journal of Sport Psychology in Action, 4(2), 97-108. DOI:10.1080/21520704.2013.764560

Gleeson, N. P., Parfitt, G., Doyle, J. \& Rees, D. (2005). Reproducibility and efficacy of the performance profile technique. Journal of Exercise Science and Fitness, 3(2), 66-73.

Gould, D., \& Carson, S. (2007). Psychological preparation in sport. In B. Blumenstein, R. Lidor, \& G. Tenenbaum (Eds.), Psychology of sport training. Perspectives on sport and exercise psychology, Vol 2 (pp. 115-136). Oxford: Meyer \& Meyer Sport.

Hulkari, K. (2006). Työssäoppimisen laadun käsite, itsearviointi ja kehittäminen sosiaali- ja terveysalan ammatillisessa peruskoulutuksessa [The concept of the quality of practical vocational training, selfevaluation, and development in upper secondary social and health care education]. (PhD Diss., University of Tampere, Tampere, Finland.)

Ivankova, N. V., Creswell, J. W., \& Stick, S. L. (2006). Using miced methods sequential explanatory design: From theory to practice. Field Methods, 18(1), 3-20.

Karjalainen, L. (2007). Kansainvälisen korkeakouluverkoston kebittäminen. Arviointitutkimus Barents Specialist -hankkeesta Rovaniemen ammattikorkeakoulussa [Development of an international higher education network. An evaluation study of the Barents Specialist project at the Rovaniemi University of Applied Sciences]. (PhD Diss., University of Lapland, Rovaniemi, Finland.) 
Nikupeteri, T., Uusiautti, S., \& Määttä, K. (2014). Young athletes’ perceptions of a psychological preparation intervention. International Journal of Human Sciences, 11(2), 609-624. doi: 10.14687/ijhs.v11i2.2941

Kremer, J., \& Moran, A. (2008). Swifter, higher, stronger. The history of sport psychology. The Psychologist, 21(8), 740-742.

Kuusela, P. (2004). Sosiaalisen maailman tasot ja toimijat. Esseitä sosiaalitieteiden ja arviointitutkimuksen metodologiasta [The levels and actors of the social world. Essays on the methodology of social sciences and evaluation research]. Kuopio: Unipress.

Laitinen, I. (2008). Autenttinen evaluaatiotekniikkea [Authentic evaluation technique]. (PhD Diss., University of Lapland, Rovaniemi, Finland.)

Lincoln, Y. S., \& Guba, E. G. (1985). Naturalistic inquiry. Thousand Oaks, CA: Sage.

Lintunen, T., Rovio, E., Haarala, S., Orava, M., Westerlund, E., \& Ruiz, M. (2012). Urheilupsykologia, liikuntapsykologia ja valmennuksen psykologia [Sport psychology, exercise psychology, and training psychology]. In L. Matikka \& M. Roos-Salmi (Eds.), Urheilupsykologian perusteet [Basics of sport psychology] (pp. 30-39). Helsinki: Liikuntatieteellinen seura.

Matikka, L. (2012). Urheilupsykologian kehitys tieteen ja ammattikäytäntöjen vuorovaikutuksessa [The development of sport psychology in the interaction between sciences and professional practices]. In L. Matikka \& M. Roos-Salmi (Eds.), Urheilupsykologian perusteet [Basics of sport psychology] (pp. 23-29). Helsinki: Liikuntatieteellinen seura.

Martindale, R. J., Collins, D., \& Daubney, J. (2005). Talent development: a guide for practice and research within Sport. Quest, 57(4), 353-375. DOI:10.1080/00336297.2005.10491862

Matikka, L., \& Roos-Salmi, M. (2012). Aluksi [Introduction]. In L. Matikka \& M. Roos-Salmi (Eds.), Urheilupsykologian perusteet [Basics of sport psychology] (pp. 11-22). Helsinki: Liikuntatieteellinen seura.

Messick, S. (1995). Validity of psychological assessment: validation of inferences from persons' responses and performances as scientific inquiry into score meaning. American Psychologist, 50, 741 749.

Morgan, W. P. (1974). Selected psychological considerations in sport. Research Quarterly. American Alliance for Health, Physical Education and Recreation, 45(4), 374-390. DOI:10.1080/10671315.1974.10615285

Määttä, K., \& Uusiautti, S. (Eds.) (2014). Time for health education. Frankfurt am Main: Peter Lang.

Newman, J., \& Crespo, M. (2008). Performance profiling in tennis. International Tennis Federation. ITF Coaching and Sport Science Review, 15(44), 12-16.

Nikander, A. (2002). Pelaajille vastuuta. Interventiotutkimus 17-19-vuotiaiden poikien jalkapallovalmennuksessa [More responsibility for players. An intervention research on soccer coaching of 17-19-year-old boys]. (Lic. Diss., University of Jyväskylä, Jyväskylä, Finland.)

Orlick, T., \& Partington, J. (1988). Mental links to excellence. The Sport Psychologist, 2, 105-130.

Robson, C. (2001). Käytännön arvioinnin perusteet. Opas evaluaation tekijöille ja tilaajille [Basics of practical evaluation. Manual for evaluators and orderers]. Helsinki: Tammi.

Rovio, E. (2002). Joukkeueellinen yksilö̈tä. Toimintatutkimus psyykkeisen valmennuksen objelman sunnnittelusta, toteuttamisesta ja arvioinnista poikien jääkiekkkojonkkueessa [A team of individuals. An action research about planning, realization, and evaluation of a psychological preparation program in boys' ice hockey team]. Jyväskylä: LIKES.

Scanlan, T. K., \& Lewthwaite, R. (1986). Social psychological aspects of competition for male youth sport participants: IV predictors of enjoyment. Journal of Sport Psychology, 8, 25-35. 
Nikupeteri, T., Uusiautti, S., \& Määttä, K. (2014). Young athletes' perceptions of a psychological preparation intervention. International Journal of Human Sciences, 11(2), 609-624. doi: 10.14687/ijhs.v11i2.2941

Shenton, A. K. (2004). Strategies for ensuring trustworthiness in qualitative research projects. Education for Information, 22, 63-75.

Silva III, J. M., Conroy, D. E., \& Zizzi, S. J. (1999). Critical issues confronting the advancement of applied sport psychology. Journal of Applied Sport Psychology, 11(2), 298-320. DOI:10.1080/10413209908404206

Syrjälä, L., \& Numminen, M. (1988). Tapaustutkimus kasvatustieteessä [Case studies in educational science]. Oulu: University of Oulu.

Sääkslahti, A., Huotari, P., Luukkonen, E., Huotari, K., \& Luukkonen, U. (2008). Kuudennen luokan oppilaiden itsearvioidun ja mitatun fyysisen kunnon yhteydet [The connection between sixth-graders' self-evaluations and measured physical shaper]. Liikunta \& Tiede, 45(6), 38-43.

Tashman, L. S., \& Tenenbaum, G. (2013). Sport psychology service delivery training: the value of an interactive, case-based approach to practitioner development. Journal of Sport Psychology in Action, 4(2), 71-85. DOI:10.1080/21520704.2012.744375

Theodorakis, Y., Hatzigeorgiadis, A., Chroni, S., \& Goudas, M. (2007). Goal setting in physical education. In J. Liukkonen, Y. V. Auweele, B. Vereijken, D. Alfermann, \& Y. Theodorakis (Eds.), Psychology for physical educators. Student in focus (pp. 13-34). Champaign, IL: Human Kinetics.

Thienot, E., Jackson, B., Dimmock, J., Grove, J. R., Bernier, M., \& Fournier, J. F. (2014). Development and preliminary validation of the mindfulness inventory for sport. Psychology of Sport and Exercise, 15(1), 72-80.

Tuomi, J., \& Sarajärvi, A. (2009). Laadullinen tutkimus ja sisällön analyysi [Qualitative research and content analysis]. Helsinki: Tammi.

Vartiainen, P. (2001). Mitä on projektiarviointi? [What is project evaluation?] In P. Vartiainen (Ed.), Näkökulmia projektiarviointiin. Tasapainottelua taloudellisessa, hallinnollisessa ja sosiaalisessa kontekstissa [Perspectives on project evaluation. Balancing in the economic, administrative, and social context] (pp. 11-28). Tampere: Finnpublishers.

Virtanen, P. (2007). Arviointi. Arviointitiedon luonne, tuottaminen ja byödyntäminen [Evaluation. The nature, production, and use of evaluation information]. Helsinki: Edita Prima Oy.

Weinberg, R. S., \& Gould, D. (2007). Foundations of sport and exercise psychology. (4th ed.) Champaign, IL: Human Kinetics.

Williams, S. E., Cooley, S. J., Newell, E., Weibull, F., \& Cumming, J. (2013). Seeing the difference: developing effective imagery scripts for athletes. Journal of Sport Psychology in Action, 4(2), 109-121, DOI: $10.1080 / 21520704.2013 .781560$ 